\title{
EFFECT OF MICROBIAL ADDITIVES AND COMPOST TEA ON GROWTH AND PRODUCTIVITY OF WHEAT PLANTS FERTILIZED BY MINERAL NITROGEN IN SANDY SOIL
}

\author{
Y. A. El-Tahlawy \\ Agricultural Microbiology Department, Soils, Water and Environ. Res. Inst., ARC, \\ Giza, Egypt.
}

Received: Oct. 10,2018

Accepted: Oct. 20,2018

\begin{abstract}
Because of widespread criticisms of extensive usage of the synthetic agrochemicals, the most research papers have an interest in the clean and sustainable agricultural practices with attention in resurgence environmental health. A field experiment was conducted in the sandy soil during winter season of 2015/2016 at experimental farm, ARC, Ismaillia Governorate, Egypt to study the effect of biological (microbial additives), organic (compost tea) fertilization and their combination on rhizosphere properties, growth and productivity of wheat crop under different levels of mineral nitrogen fertilizer. The microbial additive was applied as consortium of Serratia marcescens, Pseudomonas fluorescens, Azorhizobium caulinodans and Paenibacillus polymyxa, which cultured on commercial medium. Compost tea was used as organic fertilizer while nitrogen levels were applied at a rate of 50,75 or $100 \mathrm{~kg} \mathrm{~N} / \mathrm{fed}$. The experimental treatments were planned in a one way randomized complete block design with three replicates. The obtained data showed that the rhizosphere activity of wheat plants was enhanced due to the addition of microbial additives in combined with compost tea and high dose of nitrogen fertilizer. Wheat plants exhibited significant responses to studied treatments with respect to vegetative growth, total nutrients content, wheat yield and yield attributes. The application of combination of microbial additives and compost tea with $75 \mathrm{~kg} \mathrm{~N} / \mathrm{fed}$ revealed optimum treatment in terms of vegetative growth, total nutrients content, wheat yield and yield components.
\end{abstract}

Key words: Bioorganic fertilizers, Compost tea, Microbial activity, Mineral nitrogen fertilizer, Wheat.

\section{INTRODUCTION}

In recent years, because of widespread criticisms of extensive usage of the synthetic agrochemicals, the most research papers have an interest in the clean and sustainable agricultural practices with attention in resurgence environmental health. To achieve such approach, there is an increase interest in the dependence on biofertilizers and/or organic fertilizers as an alternative to or at least reduce the reliance on synthetic fertilizers or chemicals.

The rhizosphere concept was elaborated in 1904 by Lorenze Hiltner and progressively reported as a hot spot of microbial activities in response to the plant's roots exudates or rhizodeposits (Bakker et al., 2013 and Reinhold-Hurek et al., 2015). Ever since then, the prospect interactions between the roots and microorganisms have an attention by various disciplines resulted in elaboration many terms of the beneficial microbes act in the plant root zone. Plant growth-promoting rhizobacteria (PGPR) were first coined by Kloepper and Schroth (1978) to describe soil bacteria that colonize the roots of plants following inoculation onto seeds, and that enhance plant growth. Plant growth promoting and bio-protecting rhizobacteria (PGPBR); plant health promoting rhizobacteria (PHPR), yield increasing 
bacteria (YIB) or plant growth promoting and bioprotecting rhizobacteria (PGPBR) also have been described by many authors (Chen et al., 1996; Luz, 2001 and Reimann and Sikora, 2003). According to Ahmad et al. (2011) the rhizosphere effect is about 0-2 $\mathrm{mm}$ from the root surface by which the soil significantly influenced as nearly $49 \%$ of all photosynthetically fixed carbon being transferred to the rhizosphere through root exudates which stimulate microbial proliferation.

Compost tea as a popular one of the compost derivatives are considered the active form of organic matter, where the compost is steeped in water for a period of time with or without additives that are intended to increase microbial population densities (Scheuerell and Mahaffee, 2002). Thus, the purpose of compost steeping is transferring soluble organic matter, beneficial microorganisms, microbial metabolites as well as macroand micronutrients into a solution of compost tea. Compost tea could applied as a foliar spray or soil drench. It has been demonstrated to improve soil health, plant yield and nutritional quality by various mechanisms including enhancement of beneficial microbial communities and their activities on agricultural soils and plants; improving mineral nutrient status of plants and/or inducing the production of plant defense compounds that may have beneficial bioactivities in humans (Pant et al., 2009; El-Gizawy et al., 2013; Kim et al., 2015 and Fouda and Ali, 2016). However, most of research studies have been target the potential of compost tea for control of plant disease with little work has been done to investigate the effect of combination between microbial additives and compost tea on yield and nutritional quality of cereal crops by way of stimulate the nutrient use efficiency mechanism.

The object of the current study is to investigate the effect of biological, organic fertilizers and their combination under mineral nitrogen fertilization levels on the growth and productivity of wheat plants in sandy soil

\section{MATERIALS AND METHODS \\ Microbial additive:}

The microbial additives of plant growth promoting rhizobacteria (PGPRs) namely Serratia marcescens (strain WW4), Pseudomonas fluorescens (strain IFO. 2034), Azorhizobium caulinodans (strain IRBG-314) and Paenibacillus polymyxa (local isolate) were supplied by Microbiology Department, Soils, Water and Environment Research Institute (SWERI), Agricultural Research Center (ARC), Giza, Egypt. Peptone glycerol broth (Grimont and Grimont, 2006), nutrient broth, King's-B broth (Atlas, 2010) and TGYE broth (Ladha et al., 1989) were used as basal media for cultivation of $S$. marcescens, $P$. polymyxa, $P$. fluorescens and $A$. caulinodans, respectively. Each bacterial culture was incubated at $28^{\circ} \mathrm{C}$ for 3 days on rotatory shaker. Afterwards, mixture of PGPRs inoculants formulated of equal portions from the abovementioned microbial cultures and grown on commercial media composed of $5 \mathrm{~g} / \mathrm{l}$ maize gluten, $0.2 \mathrm{~g} / \mathrm{l}$ yeast extract, $10 \mathrm{ml}$ glycerol, $0.5 \mathrm{~g} / \mathrm{l}$ $\mathrm{KH}_{2} \mathrm{PO}_{4} ; 0.2 \mathrm{~g} / \mathrm{l} \mathrm{MgSO}_{4} .7 \mathrm{H}_{2} \mathrm{O}$ and $0.1 \mathrm{~g} / \mathrm{l}$ $\mathrm{NaCl}$. The consortium of PGPRs was incubated at $28^{\circ} \mathrm{C}$ for three days on rotatory shaker before usage.

\section{Compost Tea:}

Aerated compost tea was prepared using matured compost made from rice straw mixed with farmyard manure, rock phosphate, feldspar, bentonite, urea and elemental sulfur at rates of $100,50,50$, 100,10 and $10 \mathrm{~kg}$ /ton rice straw respectively as well as vinasse rates of 1 l/ton rice straw which had been composted in an aerobic heap for four months. Some properties of compost are shown in Table (1). 
Table 1: Some properties of compost

\begin{tabular}{|c|c|c|}
\hline Property & Unit & Value \\
\hline pH (1:10) & - & 7.2 \\
\hline EC $(1: 10)$ & $\mathrm{dS} \mathrm{m}^{-1}, 25^{\circ} \mathrm{C}$ & 5.32 \\
\hline Organic carbon & $\%$ & 37.81 \\
\hline Organic matter & $\%$ & 65.03 \\
\hline Total nitrogen & $\%$ & 1.24 \\
\hline Ammonium nitrogen & $\mathrm{mg} \mathrm{kg}^{-1}$ & 373.23 \\
\hline Nitrate nitrogen & $\mathrm{mg} \mathrm{kg}^{-1}$ & 112.51 \\
\hline Total Available $-\mathbf{N}$ & $\mathrm{mg} \mathrm{kg}^{-1}$ & 485.74 \\
\hline Available-P & $\mathrm{mg} \mathrm{kg}^{-1}$ & 258.61 \\
\hline Available-K & $\mathrm{mg} \mathrm{kg}^{-1}$ & 783.73 \\
\hline$E_{4} / E_{6}$ ratio (in aqueous extract) & - & 3.52 \\
\hline Total count of bacteria & (cfu/g) & $4.2 \times 10^{6}$ \\
\hline Total count of fungi & (cfu/g) & $1.8 \times 10^{4}$ \\
\hline Total count of actinomycetes & (cfu/g) & $2.5 \times 10^{5}$ \\
\hline${ }^{* * G e r m i n a t i o n ~ t e s t ~ o f ~ c r e s s ~ s e e d s ~}$ & $\%$ & 92 \\
\hline
\end{tabular}

$E_{4} / E_{6}$ : Extinction coefficient is optical densities of compost aqueous extract (1:10) measured at 465 (E4) and $665 \mathrm{~nm}(\mathrm{E} 6)$ wavelengths.

${ }^{* *}$ cress seeds incubated for $\mathbf{4 8} \mathrm{hrs}$.

To prepare compost tea, fifteen $\mathrm{kg}$ of mature compost (in $150 \mathrm{~L}$ plastic barrel) blended with $100 \mathrm{~L}$ tap water (previously stored for $24 \mathrm{hrs}$. to avoid the harmful effect of chlorine on microbial load of compost) and some chemical additives, namely $0.5 \mathrm{I}$ vinasse, $0.5 \mathrm{~kg}$ sucrose, 0.5 $\mathrm{kg}\left(\mathrm{NH}_{4}\right)_{2} \mathrm{SO}_{4}, 25 \mathrm{~g} \mathrm{MgSO}{ }_{4} .7 \mathrm{H}_{2} \mathrm{O}, 250 \mathrm{ml}$ humic substances and $10 \mathrm{~g} \mathrm{NaCl}$. This mixture was thoroughly aerated for three days with using air compressor connected with drill PVC pipe dipped in the barrel. After the brewing period was elapsed, the mixture was filtered on a 100-mesh screen to become ready to use. The procedure and methods of analysis for compost or compost tea were followed as described by Page et al.
(1982). The main characters of produced compost tea are shown in Table (2).

\section{Experimental design and management:}

A field experiment was conducted in the sandy soil at Ismaillia Experimental Research Station, ARC, Ismaillia Governorate, Egypt during winter season of 2015/2016 to study the effect of individual and combined applications of microbial additives, compost tea (bioorganic fertilizers) on growth and productivity of wheat crop (Triticum aestivum cv. Giza 168) under different levels of mineral nitrogen fertilizer using sprinkler irrigation system. Some physiochemical and biological characteristics of used soil were carried 
out according to methods of Page et al. (1982) and the obtained data are recorded in Table (3).

The experiment was planned in a one way randomized complete blocks design with three replicates at plot area of $\mathbf{2 1} \mathrm{m}^{2}$ as an experimental unit. All experimental units received mature compost (Table 1) at a rate of $\mathbf{1 0} \mathrm{ton} / \mathrm{fed}$, the recommended dose of phosphorus $(200 \mathrm{~kg} / \mathrm{fed}$ superphosphate "15.5\% $\left.\mathrm{P}_{2} \mathrm{O}_{5}{ }^{\prime \prime}\right)$ and potassium (1.. $\mathrm{kg} / \mathrm{fed}$ potassium sulphate "48\% $\mathrm{K}_{2} \mathrm{O}$ "). Also, mineral nitrogen fertilizer was added at a rate of 50,75 and $100 \mathrm{~kg} \mathrm{~N}$ per fed in the form of ammonium sulphate $(20.5 \% \mathrm{~N})$ in four equal splits at $10,20,3$ and 40 days after sowing. Phosphorus and compost were added during soil preparation, while potassium was added after 15 and 30 days of sowing in equal two doses. The microbial additives and compost tea were applied as foliar spray and soil drench at a rate of 10 and 75 L/fed $(11.25 \mathrm{~kg}$ compost per 75 liter), respectively, in three equal splits 30,45 and 60 days after sowing. The treatments were arranged as the following:

$\mathrm{T} 1=$ Recommended nitrogen $(100 \mathrm{~kg}$ N/fed).

$\mathrm{T} 2=$ Microbial additives $+50 \mathrm{~kg} \mathrm{~N} / \mathrm{fed}$.

T3 $=$ Microbial additives $+75 \mathrm{~kg} \mathrm{~N} / \mathrm{fed}$.

T4 $=$ Microbial additives $+100 \mathrm{~kg} \mathrm{~N} / \mathrm{fed}$.

$\mathrm{T} 5=$ Compost tea $+\mathbf{5 0} \mathbf{~ k g ~ N} / \mathrm{fed}$.

T6 $=$ Compost tea $+75 \mathrm{~kg} \mathrm{~N} / \mathrm{fed}$.

T7 = Compost tea $+100 \mathrm{~kg} \mathrm{~N} / \mathrm{fed}$.

T8 $=$ Microbial additives + compost tea + $50 \mathrm{~kg} \mathrm{~N} / \mathrm{fed}$.

T9 $=$ Microbial additives + compost tea + $75 \mathrm{~kg} \mathrm{~N} / \mathrm{fed}$.

T10 $=$ Microbial additives + compost tea + $100 \mathrm{~kg} \mathrm{~N} / \mathrm{fed}$.

Table 2: Some properties of compost tea

\begin{tabular}{lcc}
\hline Property & Unit & Compost tea \\
\hline $\mathrm{pH}$ & - & 6.85 \\
$\mathrm{EC}$ & $\mathrm{dS} / \mathrm{m}, 25^{\circ} \mathrm{C}$ & 3.35 \\
Organic carbon & $\%$ & 5.80 \\
Organic matter & $\%$ & 9.98 \\
Ammonium nitrogen & $\mathrm{mg} / \mathrm{l}$ & 102.8 \\
Nitrate nitrogen & $\mathrm{mg} / \mathrm{l}$ & 24.60 \\
Total soluble-N & $\mathrm{mg} / \mathrm{l}$ & 127.4 \\
Soluble-P & $\mathrm{mg} / \mathrm{l}$ & 38.60 \\
Soluble-K & $\mathrm{mg} / \mathrm{l}$ & 312.0 \\
$\mathrm{E}_{4} / \mathrm{E}_{6}$ ratio (in aqueous extract) & - & 3.92 \\
Total count of bacteria & $\mathrm{cfu} / \mathrm{ml}$ & $6.3 \times 10^{7}$ \\
Total count of fungi & $\mathrm{cfu} / \mathrm{ml}$ & $5.1 \times 10^{4}$ \\
Total count of actinomycetes & $\mathrm{cfu} / \mathrm{ml}$ & $1.6 \times 10^{6}$ \\
$* *$ Germination test of cress seeds & $\%$ & 94 \\
\hline E $_{4} / \mathrm{E}_{6}:$ Extinction coefficient is optical densities of compost tea measured at $465(\mathrm{E} 4)$ and $665 \mathrm{~nm}$ \\
(E6) wavelengths
\end{tabular}


Table 3: Some physiochemical and biological characteristics of used soil

\begin{tabular}{|c|c|}
\hline Property & Value \\
\hline \multicolumn{2}{|l|}{ Mechanical analysis: } \\
\hline Sand \% & 90.30 \\
\hline Silt \% & 4.90 \\
\hline Clay \% & 4.80 \\
\hline Texture grade & Sandy \\
\hline Saturation percent (S.P. \%) & 21.13 \\
\hline $\mathrm{CaCO}_{3}(\%)$ & 1.72 \\
\hline pH (soil paste) & 7.57 \\
\hline $\mathrm{EC}\left(\mathrm{dS} / \mathrm{m}, 25^{\circ} \mathrm{C}\right)$ & 0.32 \\
\hline \multicolumn{2}{|l|}{ Soluble cations (meq/L): } \\
\hline $\mathrm{Ca}^{++}$ & 0.84 \\
\hline $\mathbf{M g}^{++}$ & 0.52 \\
\hline $\mathrm{Na}^{+}$ & 1.51 \\
\hline $\mathrm{K}^{+}$ & 0.15 \\
\hline \multicolumn{2}{|l|}{ Soluble anions (meq/L): } \\
\hline $\mathrm{CO}={ }_{3}$ & 0.00 \\
\hline $\mathrm{HCO}_{3}$ & 1.72 \\
\hline $\mathrm{Cl}^{-}$ & 0.68 \\
\hline $\mathrm{SO}_{4}$ & 0.62 \\
\hline Organic matter \% & 0.31 \\
\hline Total nitrogen \% & 0.03 \\
\hline Total soluble- $\mathbf{N}\left(\mathrm{mg} \mathrm{kg}^{-1}\right)$ & 16.23 \\
\hline Available phosphorus $\left(\mathrm{mg} \mathrm{kg}^{-1}\right)$ & 5.90 \\
\hline Available potassium $\left(\mathrm{mg} \mathrm{kg}^{-1}\right)$ & 58.70 \\
\hline \multicolumn{2}{|l|}{ DTPA-extractable $\left(\mathrm{mg} \mathrm{kg}^{-1}\right)$ : } \\
\hline $\mathrm{Fe}$ & 2.30 \\
\hline $\mathrm{Mn}$ & 0.50 \\
\hline $\mathrm{Zn}$ & 0.60 \\
\hline $\mathrm{Cu}$ & 0.22 \\
\hline Dehydrogenase enzymes (mg TPF/g dry soil/day) & 18.43 \\
\hline Total count of bacteria log N. (cfu/g dry soil) & 4.86 \\
\hline Total count of fungi log N. (cfu/g dry soil) & 3.56 \\
\hline Total count of actinomycetes log N. (cfu/g dry soil) & 4.11 \\
\hline
\end{tabular}


Rhizosphere analysis:

After 80 days from sowing, the plants uprooted and samples of rhizosphere soil was obtained by gently shaking the roots with adhering soil to free them from the mass of soil. The rhizosphere and bulk soil were collected and stored at $4^{\circ} \mathrm{C}$ for microbiological analysis.

The microbial activity in the rhizosphere soil was assayed by measuring the dehydrogenase enzymes based on the reduction of 2,3,5triphenyltetrazolium chloride (TTC) to the red-colored formazan (TPF) according to Casida (1977)

To estimate the total number of soil bacteria, counts were calculated based on serial 10-fold dilutions using the pour plate method. The bacteria were counted in rhizosphere and non-rhizosphere soil using soil extract agar (Atlas, 2010) and the plates were incubated at $28^{\circ} \mathrm{C}$ in the dark. Colony-forming units (CFU) were recorded after one week. A numerical value for the rhizosphere: soil ratio (R/S ratio) representing microbial counts in the rhizosphere divided by the microbial counts in the non-rhizosphere soil, was used as an index of the rhizosphere effect on the microbial population.

\section{Plant analysis:}

After 80 days from sowing, wheat plants were sampled and assayed for plant height, shoot and root dry weight, root surface area and the total nutrients content (N, P and $k$ of shoot). Root surface area was estimated using an acid adsorption method according to (Chowdhury and Weatherley, 1990) and expressed as $\mathrm{ml}$ equivalent of $0.01 \mathrm{~N}$ $\mathrm{NaOH}$. A wet digestion of oven dried plant (at $70^{\circ} \mathrm{C}$ for $48 \mathrm{hrs}$.) material was performed using concentrated sulphuric acid and perchloric acid as a catalyst. Total nitrogen was determined using the micro Kjeldahl method, phosphorus was determined Spectrophotometrically using ammonium molybdate and stannous chloride reagents and potassium was determined using Flame photometer (Chapman and Pratt, 1961).

At harvest, plant samples were collected using a wooden frame $(0.5 \times 0.5$ $\mathrm{m}$ ) to record grain yield (ton/fed), straw yield (ton/fed), 1000 grain weight (g), seed crude protein (\%) and straw crude protein (\%). The crude protein in grains and straw were estimated by multiplying the nitrogen percent by 5.7 factor according to AOAC (1998).

\section{Statistical analysis:}

Statistical analysis of data was done by the analysis of variance (ANOVA) according to the methods described by Snedecor and Cochran (1980). Multiple comparisons of treatment means were done by least significant difference test (LSD) at $p \leq 0.05$ level. The analysis was performed using CoStat program ver. 6.4, CoHort software.

\section{RESULTS AND DISCUSSION \\ Rhizosphere properties:}

Data in Table (4) shows some aspects of wheat plants rhizosphere, affected by mineral nitrogen fertilization or individually and in combination with microbial additives and compost tea alone and together, as estimated in terms of dehydrogenases activity and rhizosphere effect. Dehydrogenase enzymes activity significantly increased in a progressive manner as the mineral nitrogen fertilizer increased under the treatments of microbial additives or compost tea. Under 50 or $75 \mathrm{~kg} \mathrm{~N} / \mathrm{fed}$, the added compost tea recorded higher values of dehydrogenase enzymes as compared with microbial additives. However, the combined application of microbial additives and compost tea highly boosted the microbial activity to record the highest values of dehydrogenase enzymes. The application of $75 \mathrm{~kg} \mathrm{~N} / \mathrm{fed}$ with combined application 
(T9) of microbial additives and compost tea revealed a non-significant variation in dehydrogenase enzymes as compared with treatments that received $100 \mathrm{~kg}$ $\mathrm{N} / \mathrm{fed}$. The added compost tea increased microbial activity by 14.07 and $11.87 \%$ over microbial additives under 50 and 75 kg N/fed, respectively. While the combination between compost tea and microbial additive, the dehydrogenase values increased by 37.47 and $28.84 \%$ over microbial additives and by 20.52 and $\mathbf{1 5 . 1 7 \%}$ over compost tea under 50 and 75 kg N/fed, respectively.

Table 4: Effect of microbial additives and compost tea under different levels of nitrogen on some aspects of rhizosphere properties after $\mathbf{8 0}$ days from sowing

\begin{tabular}{|c|c|c|c|c|}
\hline Treatments & $\begin{array}{l}\text { Dehydro- } \\
\text { genases } \\
\text { (mg TPFlg } \\
\text { dry } \\
\text { soil/day) }\end{array}$ & $\begin{array}{l}\text { Total } \\
\text { bacteria in } \\
\text { rhizosphe } \\
\text { re (CFU/g } \\
\left.\text { soil } \times 10^{6}\right)\end{array}$ & $\begin{array}{c}\text { Total } \\
\text { bacteria in } \\
\text { bulk soil } \\
(\text { CFU/g } \\
\left.\text { soil } \times 10^{6}\right)\end{array}$ & $\begin{array}{l}\text { Rhizo- } \\
\text { sphere } \\
\text { effect } \\
\text { (R/S ratio) }\end{array}$ \\
\hline Recommended-N (T1) & $133.88 b$ & 3.67 & 0.34 & 10.75 \\
\hline Microbial additives (MA) + $50 \mathrm{Kg} \mathrm{N} / \mathrm{fed}(\mathrm{T} 2)$ & 88.73f & 4.67 & 0.32 & 14.55 \\
\hline Microbial additives (MA) + 75 kg N/fed (T3) & 110.41d & 5.67 & 0.33 & 16.92 \\
\hline Microbial additives (MA) + $100 \mathrm{~kg} \mathrm{~N} / \mathrm{fed}(\mathrm{T} 4)$ & $139.66 \mathrm{ab}$ & 7.00 & 0.35 & 19.97 \\
\hline Compost tea (CT) + $50 \mathrm{Kg} \mathrm{N} / \mathrm{fed}(\mathrm{T} 5)$ & $101.21 \mathrm{e}$ & 5.00 & 0.35 & 14.46 \\
\hline Compost tea (CT) + $75 \mathrm{~kg} \mathrm{~N} / \mathrm{fed}(\mathrm{T} 6)$ & 123.51c & 6.67 & 0.36 & 18.46 \\
\hline Compost tea (CT) + 100 kg N/fed (T7) & 141.02ab & 7.33 & 0.37 & 20.00 \\
\hline$M A+C T+50$ kg N/fed (T8) & 121.98c & 6.00 & 0.36 & 16.61 \\
\hline MA + CT + 75 kg N/fed (T9) & $142.25 a b$ & 7.67 & 0.37 & 20.72 \\
\hline $\mathrm{MA}+\mathrm{CT}+100 \mathrm{~kg} \mathrm{~N} / \mathrm{fed}(\mathrm{T} 10)$ & $146.64 a$ & 7.33 & 0.38 & 19.33 \\
\hline LSD $_{0.05}$ & 5.03 & - & - & - \\
\hline
\end{tabular}

The means of the same letter are not significantly different at the $5 \%$ level according to LSD test.

Regarding the microbial count of bacteria, the total number of bacterial in the rhizosphere region exhibited highly variation as compared with that in the bulk soil. Such variation in rhizosphere bacteria positively reflected on the rhizosphere effect (R/S ration) values. The lowest value was recorded with the recommended-N treatment (T1) for rhizosphere bacteria and rhizosphere effect. The highest values were achieved due to application of $75 \mathrm{~kg} \mathrm{~N} / \mathrm{fed}$ (T9) followed by treatments of $100 \mathrm{k}$ N/fed with microbial activity, compost tea or combination of them.

Soil dehydrogenase enzymes are one of the main components of soil enzymatic activities that participate in all the biochemical routes of soil biogeochemical cycles for the maintenance of soil fertility (Kumar et al., 2013). Compost tea is a liquid extract of compost that contains microorganisms, organic matter, nutrients and growth factors that could potentially enhance the microbial activity in the rhizosphere of 
plant which indicated by high values of dehydrogenases. The obtained result in harmony with El-Gizawy et al. (2013) who documented that inoculation with compost and foliar compost tea applications generally enhanced the bacterial counts, dehydrogenases (DHA) and nitrogenase $\left(\mathrm{N}_{2}\right.$-ase) activities.

The ratio of rhizosphere and bulk is widely used to evaluate the degree of rhizosphere effect that could help the plant by maintaining the recycling of nutrients, through the production of hormones, helping to provide resistance to microbial diseases and to aid tolerance to toxic compounds (Morgan et al., 2005 and Dotaniya and Meena, 2014). According to Momin and Dhere (2013), the high bacterial population is attributed to symbiotic and non-symbiotic association between the roots of the plants and the bacteria owing to this positive association there are more nutrients and hence the soil is more fertile and therefore the count of microorganism is very high in rhizosphere as compared to nonrhizosphere. these results support the aforementioned statement since the R/S ratio was positively correlated with the root surface area of wheat plants. Also, these findings are consistent with Guo et al. (2015) and Zhu et al. (2016) in the microbial biomass is positively correlated with soil organic carbon and total nitrogen because the evident increase in the rhizosphere bacteria due to the addition of microbial additives in combined with compost tea and high dose of nitrogen fertilizer.

Table 5: Effect of microbial additives and compost tea under different levels of nitrogen on some wheat growth parameters after 80 days from sowing

\begin{tabular}{|c|c|c|c|c|}
\hline${ }^{2}-{ }^{2}$ & $\begin{array}{l}\text { Plant } \\
\text { height } \\
(\mathrm{cm})\end{array}$ & $\begin{array}{c}\text { Shoot } \\
\text { Dry } \\
\text { weight } \\
\text { (g/plant) }\end{array}$ & $\begin{array}{c}\text { Root } \\
\text { Dry } \\
\text { weight } \\
\text { (g/plant) }\end{array}$ & $\begin{array}{c}\text { Root } \\
\text { surface } \\
\text { area } \\
(\mathrm{ml} \mathrm{NaOH})\end{array}$ \\
\hline Recommended-N (T1) & $79.56 a$ & $3.30 \mathrm{ab}$ & $1.28 \mathrm{a}$ & 25.01d \\
\hline Microbial additives (MA) + $50 \mathrm{Kg} \mathrm{N} / \mathrm{fed}(\mathrm{T} 2)$ & $45.11 \mathrm{~g}$ & $1.94 \mathrm{~g}$ & $0.96 f$ & $16.02 \mathrm{fg}$ \\
\hline Microbial additives (MA) + 75 kg N/fed (T3) & $63.85 d$ & $2.56 d$ & $1.15 \mathrm{~cd}$ & 20.71e \\
\hline Microbial additives (MA) + $100 \mathrm{~kg} \mathrm{~N} / \mathrm{fed}(\mathrm{T} 4)$ & $71.79 c$ & $3.17 b$ & $1.24 a b$ & 23.22d \\
\hline Compost tea (CT) + $50 \mathrm{Kg} \mathrm{N} / \mathrm{fed}(\mathrm{T} 5)$ & $52.04 f$ & $2.11 f$ & $1.05 \mathrm{e}$ & $16.74 \mathrm{fg}$ \\
\hline Compost tea (CT) + $75 \mathrm{~kg} \mathrm{~N} / \mathrm{fed}(\mathrm{T} 6)$ & $73.37 \mathrm{bc}$ & $2.81 \mathrm{c}$ & $1.19 \mathrm{bc}$ & 24.02cd \\
\hline Compost tea (CT) + $100 \mathrm{~kg} \mathrm{~N} / \mathrm{fed}(\mathrm{T} 7)$ & $74.52 \mathrm{bc}$ & $3.23 a b$ & $1.25 \mathrm{ab}$ & 26.11bcd \\
\hline$M A+C T+50$ kg N/fed (T8) & $58.72 e$ & $2.38 \mathrm{e}$ & $1.13 d$ & $17.43 f$ \\
\hline MA + CT + 75 kg N/fed (T9) & $75.87 \mathrm{abc}$ & $3.28 \mathrm{ab}$ & $1.26 a$ & $28.37 b$ \\
\hline $\mathrm{MA}+\mathrm{CT}+100 \mathrm{~kg} \mathrm{~N} / \mathrm{fed}(\mathrm{T} 10)$ & $77.67 \mathrm{ab}$ & $3.35 a$ & $1.27 \mathrm{a}$ & $30.95 a$ \\
\hline LSD $_{0.05}$ & 5.03 & 0.15 & 0.05 & 2.40 \\
\hline
\end{tabular}

The means of the same letter are not significantly different at the $5 \%$ level according to LSD test. 


\section{Morphological growth parameters of wheat plants:}

Data in Table (5) shows some morphological aspects of wheat plants due to the effect of added mineral nitrogen fertilization individually and in combination with microbial additives and compost tea alone and together. The studied treatments have significant variations on the estimated growth parameters. The highest values of plants were appeared due to application of compost tea alone or its combination with microbial additives under nitrogen levels of 75 or $100 \mathrm{~kg} \mathrm{~N} / \mathrm{fed}(\mathrm{T} 1, \mathrm{~T} 10, \mathrm{~T}$, T7, T6 and T4) compared with the values resulted from the treatments of microbial additives with 50 and $75 \mathrm{~kg} \mathrm{~N} / \mathrm{fed}$ of mineral nitrogen with microbial additives (T2 and T3) and also these obtained with low nitrogen level (50 kg N/fed) in combination with compost tea (T5) or with combination (T8).

Concerning the data of shoot dry weight, the obtained data show that at the rate of added mineral nitrogen the combined application of microbial additives with compost tea resulted in high values of shoots dry weight compared with their individualized applications. The shoot dry weight gradually increased with increase in nitrogen fertilizer especially with microbial additives (T2 to T4) or with compost tea treatments (T5 to T7). The applications of compost tea increased shoot dry weight by $8.76,9.77$ and $1.89 \%$ over treatments of microbial additives with additions of 50,75 and $100 \mathrm{~kg} \mathrm{~N} / \mathrm{fed}$, respectively. With all application rates of mineral nitrogen, the combined application of microbial additives and compost tea increase the shoot dry weight by $22.68,28.13$ and $5.68 \%$ over individual microbial additives or by 12.8 , 16.73 and $3.72 \%$ over the individual treatments of compost tea with 50, 75 and $100 \mathrm{~kg} \mathrm{~N} / \mathrm{fed}$, respectively.
With regard to the data of root dry weight, data in Table (5) shows that the treatment of recommend nitrogen dose (T1) recorded the maximum value with non-significant difference comparing to microbial additives (T4) and compost tea (T7) that received $100 \mathrm{~kg} \mathrm{~N} / \mathrm{fed}$ or with combined treatment of microbial additives and compost tea that received 75 or $100 \mathrm{~kg} \mathrm{~N} / \mathrm{fed}$ (T8 or T10). The effect of microbial additives on root dry weight gradually increased with addition of nitrogen fertilizer. With compost tea there are no significant effect on the increase in roots dry weight compared with those associated with the treatments of microbial additives especially under 75 and $100 \mathrm{~kg} \mathrm{~N} / \mathrm{fed}$.

Root surface area of wheat plants were significantly increased by application of microbial additives together with compost tea under $100 \mathrm{~kg}$ N/fed (T10) as compared with other treatments. The compost tea application showed higher values in the root surface area as compared with microbial additives under the same level of mineral nitrogen fertilizer. The root surface area ranged from 16.02 to $23.22 \mathrm{ml} \mathrm{NaOH}$, 16.74 to $26.11 \mathrm{ml} \mathrm{NaOH}$ and 17.43 to 30.95 $\mathrm{ml} \mathrm{NaOH}$ in the treatments of microbial additives, compost tea and combination of compost tea and microbial additives comparing with $25.01 \mathrm{ml} \mathrm{NaOH}$ for recommended-N treatment dose of nitrogen (T1) without microbial additives or compost tea.

The production of plant growth substances such as indole compounds and gibberellins by PGPRs in addition to the simulative effect of compost tea, which contains a considerable amount soluble nutrients, organic matter and growth factors, are involved in cell division and elongation in the meristmatic region of plant. Further, the accumulation of nutrients in the wheat 
due to the combined addition of microbial additives and compost tea that act in a synergistic mode to stimulate the uptake of nutrients, which have a vital role in synthesis of chlorophyll, enzymes, amino acids, proteins and the process of photosynthesis enhancement as well as assimilation rate for precursors of carbohydrates increased the vegetative growth organs. The obtained results are consistent with those reported by Kumar et al. (2015); Zewail and Ahmed (2015); Desoky and El-Sayed (2016) and Khalil and Agah (2017).

\section{Nutrients content in wheat plants:}

Data in Table (6) represent nitrogen, phosphorus and potassium uptake in the shoot as $\mathrm{mg} / \mathrm{plant}$ of wheat plants treated with microbial additives, compost tea and their combination under three rates of mineral nitrogen. The nutrient uptake was significantly responded to the studied treatments for N, P and K uptake. The maximum values (mg/plant) were recorded by the treatments of $100 \mathrm{~kg}$ N/fed without (T1) or with bioorganic addition (T10, T7 and T4) or by treatment that received $75 \mathrm{~kg}$ N/fed (T8) with combined application of microbial additives and compost tea. Data also showed that with the same level of nitrogen fertilizer (50 or $75 \mathrm{~kg} \mathrm{~N} / \mathrm{fed}$ ) compost tea application surpassed microbial additives and significantly increased the nutrient contents except for the content of potassium. However, the combination between microbial additives and compost tea (T8 to T10) appeared a maximized stimulation effect for nutrient uptake comparing with microbial additives (T2 to T4) or compost tea (T5 to T7). Under $50 \mathrm{~kg} \mathrm{N/fed,} \mathrm{the}$ combined addition of microbial additives and compost tea increased the nitrogen, phosphorus and potassium uptake by $30.07,24.76$ and $23.22 \%$ or $12.48,11.78$ and $\mathbf{1 7 . 7 6} \%$ over microbial additives or compost tea, respectively. The corresponding values under $75 \mathrm{~kg} \mathrm{~N} / \mathrm{fed}$ were 23.39 , 18.36 and $17.09 \%$ or 14.58 , 9.43 and $12.82 \%$, respectively.

Table 6: Effect of microbial additives and compost tea under different levels of nitrogen on shoot of wheat nutrient uptake ( $\mathrm{mg} / \mathrm{plant}$ ) of shoot after $\mathbf{8 0}$ days from sowing

\begin{tabular}{|c|c|c|c|}
\hline Paramters & $\begin{array}{c}\text { Total } \\
\text { nitrogen } \\
\text { content } \\
\text { (mg/plant) }\end{array}$ & $\begin{array}{c}\text { Total } \\
\text { phosphorus } \\
\text { content } \\
\text { (mg/plant) }\end{array}$ & $\begin{array}{c}\text { Total } \\
\text { potassium } \\
\text { content } \\
\text { (mg/plant) }\end{array}$ \\
\hline Recommended-N (T1) & $50.65 a$ & $23.71 \mathrm{a}$ & $61.96 \mathrm{a}$ \\
\hline Microbial additives (MA) $+50 \mathrm{Kg} \mathrm{N} / \mathrm{fed}(\mathrm{T} 2)$ & $29.10 f$ & $14.30 f$ & $39.50 \mathrm{~d}$ \\
\hline Microbial additives (MA) + 75 kg N/fed (T3) & $39.93 \mathrm{c}$ & $19.61 \mathrm{c}$ & $53.07 \mathrm{~b}$ \\
\hline Microbial additives (MA) + $100 \mathrm{~kg} \mathrm{~N} / \mathrm{fed}(\mathrm{T} 4)$ & $49.18 a$ & $22.85 a$ & $59.89 a$ \\
\hline Compost tea (CT) + $50 \mathrm{Kg} \mathrm{N} / \mathrm{fed}(\mathrm{T} 5)$ & $33.65 \mathrm{e}$ & $15.96 \mathrm{e}$ & 41.33d \\
\hline Compost tea (CT) + 75 kg N/fed (T6) & 43.00b & 21.21b & $55.46 \mathrm{~b}$ \\
\hline Compost tea (CT) + $100 \mathrm{~kg} \mathrm{~N} / \mathrm{fed}(\mathrm{T} 7)$ & $49.14 a$ & $23.19 a$ & $61.40 \mathrm{a}$ \\
\hline $\mathrm{MA}+\mathrm{CT}+50 \mathrm{~kg} \mathrm{~N} / \mathrm{fed}(\mathrm{T} 8)$ & $37.85 d$ & $17.84 d$ & $48.67 \mathrm{c}$ \\
\hline MA + CT + $75 \mathrm{~kg} \mathrm{~N} / \mathrm{fed}(\mathrm{T} 9)$ & $49.27 a$ & 23.21a & $62.57 \mathrm{a}$ \\
\hline MA + CT + 100 kg N/fed (T10) & $50.78 a$ & $23.55 a$ & $63.15 a$ \\
\hline $\operatorname{LSD}_{0.05}$ & 1.67 & 1.59 & 3.46 \\
\hline
\end{tabular}

The means of the same letter are not significantly different at the $5 \%$ level according to LSD test. 
Structural and functional characteristics of roots contribute to rhizosphere processes and both have significant influence on the capacity of roots to acquire nutrients. Roots also interact extensively with soil microorganisms which further impact on plant nutrition either directly, by influencing nutrient availability and uptake, or indirectly through plant root growth promotion (Richardson et al., 2009).

Under current study the increased total nutrients content of $\mathrm{N}, \mathrm{P}$ or $\mathrm{K}$ could be due to the stimulation of root dry weight and root surface area (Table 5) as a result of microbial additives in addition to the stimulation effect of compost tea application at rhizosphere of wheat plants. Our findings confirm the results of Rana et al. (2012) and Desoky and ElSayed (2016) whose attributed the increase of mineral content in wheat plants to the enhancement of the root growth and development due to the positive influence of microbial activity. According to Dakora and Phillips (2002), plant root exudates consist of a complex mixture of organic acid anions, phytosiderophores, sugars, vitamins, amino acids, purines, nucleosides, inorganic ions (e.g. $\mathrm{HCO}_{3}-\mathrm{OH}^{-}, \mathrm{H}^{+}$), gaseous molecules $\left(\mathrm{CO}_{2}, \mathrm{H}_{2}\right)$, enzymes and root border cells which have major direct or indirect effects on the acquisition of mineral nutrients required for plant growth. Further, Dotaniya and Meena (2014) stated that rhizospheric bacteria participate in the geochemical cycling of nutrients especially nitrogen, phosphorus and micronutrients and determine their availability for plants and enhances crop yield by increasing plant nutrient availability.

\section{Wheat yield and its attributes:}

Data in Table (7) shows the effect of bioorganic fertilization (microbial additives, compost tea and their combination) and different levels of mineral nitrogen fertilizer on wheat yield and some yield components in terms of grain yield, straw yield, 1000 grain weight seed crude protein and straw crude protein.

Table 7: Effect of microbial additives and compost tea under different levels of nitrogen on some yield parameters of wheat

\begin{tabular}{|c|c|c|c|c|c|}
\hline Paramters & $\begin{array}{c}\text { Grain } \\
\text { yield } \\
\text { (ton/fed) }\end{array}$ & $\begin{array}{c}\text { Straw } \\
\text { yield } \\
\text { (ton/fed) }\end{array}$ & $\begin{array}{c}1000 \\
\text { grain } \\
\text { weight (g) }\end{array}$ & $\begin{array}{c}\text { Seed } \\
\text { crude } \\
\text { protein } \\
(\%)\end{array}$ & $\begin{array}{c}\text { Straw } \\
\text { crude } \\
\text { protein } \\
(\%)\end{array}$ \\
\hline Recommended-N (T1) & $1.84 a$ & $2.58 a b$ & $50.49 a$ & 13.35ab & $4.51 \mathrm{a}$ \\
\hline Microbial additives (MA) $+50 \mathrm{Kg} \mathrm{N} / \mathrm{fed}(\mathrm{T} 2)$ & $1.07 f$ & $1.28 \mathrm{~g}$ & $32.03 f$ & $8.10 \mathrm{~g}$ & 2.48d \\
\hline Microbial additives (MA) + 75 kg N/fed (T3) & $1.52 \mathrm{c}$ & $1.75 d$ & 42.69c & $10.45 d$ & $3.69 c$ \\
\hline Microbial additives (MA) $+100 \mathrm{~kg} \mathrm{~N} / \mathrm{fed}(\mathrm{T} 4)$ & $1.78 a$ & $2.45 a b$ & $49.03 a$ & $12.94 b$ & $3.90 \mathrm{bc}$ \\
\hline Compost tea (CT) + $50 \mathrm{Kg} \mathrm{N} / \mathrm{fed}(\mathrm{T} 5)$ & $1.23 e$ & $1.44 f$ & $35.99 \mathrm{e}$ & $9.05 f$ & 2.95d \\
\hline Compost tea (CT) + $75 \mathrm{~kg} \mathrm{~N} / \mathrm{fed}(\mathrm{T} 6)$ & $1.64 b$ & $1.92 \mathrm{C}$ & $45.36 b$ & $11.85 \mathrm{c}$ & $4.58 a$ \\
\hline Compost tea (CT) + $100 \mathrm{~kg} \mathrm{~N} / \mathrm{fed}(\mathrm{T} 7)$ & $1.77 \mathrm{a}$ & $2.45 b$ & 48.69a & $13.12 b$ & $4.27 a b$ \\
\hline $\mathrm{MA}+\mathrm{CT}+50 \mathrm{~kg} \mathrm{~N} / \mathrm{fed}(\mathrm{T} 8)$ & $1.40 \mathrm{~d}$ & $1.59 \mathrm{e}$ & 39.73d & $9.88 \mathrm{e}$ & $3.06 \mathrm{~d}$ \\
\hline MA + CT + 75 kg N/fed (T9) & $1.80 \mathrm{a}$ & $2.54 a b$ & $49.33 a$ & $13.04 b$ & 4.31ab \\
\hline $\mathrm{MA}+\mathrm{CT}+100 \mathrm{~kg} \mathrm{~N} / \mathrm{fed}(\mathrm{T} 10)$ & $1.84 a$ & $2.59 a$ & $50.48 a$ & $13.78 \mathrm{a}$ & $4.32 \mathrm{ab}$ \\
\hline LSD $_{0.05}$ & 0.11 & 0.15 & 2.66 & 0.56 & 0.58 \\
\hline
\end{tabular}


In general, the data revealed that all yield components of wheat plants significantly responded to bioorganic and nitrogen fertilization. Irrespective of nitrogen levels all wheat yield parameters significantly responded to bioorganic fertilizers with superiority combined application of microbial additives with compost tea. On the other hand, the increase in nitrogen level within each treatment of bio-fertilizer, compost tea or combination appeared significant increments in the most of wheat yield parameters. However, the data also showed that no significant variations within the estimated growth parameters was observed between the treatments received $100 \mathrm{~kg} \mathrm{~N} / \mathrm{fed}$ (T1, T4, T7 and T10) and that received $75 \mathrm{~kg} \mathrm{~N} / \mathrm{fed}$ (T9) with combined application of microbial additives and compost tea. The combined treatments of microbial additives with compost tea raised up grain yield, straw yield, 100 grain weight, seed crude protein and straw crude protein under $50 \mathrm{~kg} \mathrm{~N} / \mathrm{fed}$ by $30.84,24.22$, $24.04,21.98$ and $23.39 \%$ or $13.82,10.42$, 10.39, 9.17 and $3.73 \%$ over microbial additives or compost tea, respectively. The corresponding increases under $75 \mathrm{~kg}$ $\mathrm{N} / \mathrm{fed}$ were 18.42, 45.14, 15.55, 24.78 and $16.80 \%$ or $9.76,32.29,8.75,10.04$ and $5.90 \%$, respectively.

The increments in wheat grain yield and its crude protein could be attributed to the stimulation effect of microbial additives and compost tea to increase the vegetative growth organs (Table, 5) and the nutrient contents (Table, 6) in plant material. Our finding in conformity with many workers (Rana et al., 2012; Desoky and El-Sayed, 2016 and El-Egami et al., 2017). Furthermore, the microorganisms that introduced into microbiome of wheat plants, either by direct microbial additives or indirect via compost tea, have a vital role to prime the plant innate immune system and confer resistance to a broad spectrum of biotic stress (Martin, 2014 and Arya et al., 2018) as well as could provide a fundamental support to the plants in tolerating abiotic stresses such as drought and salinization (Kumar et al., 2018) which reflected on the final yield and/or yield components of wheat.

\section{Conclusion}

The obtained results indicated that microbial additives application in combination with compost tea in organic farming could be used to increase the fertilizer use efficiency in sandy soil. In view of environmental pollution, the excessive use of mineral fertilizers with high costs in the production of $N, P$ and $K$ fertilizers, microbial additives and compost tea tested in our study may well be suited in combination to achieve sustainable and ecological agricultural production in sandy soils. The rhizosphere effect of wheat plants was enhanced due to the addition of microbial additives in combination with compost tea. Wheat plants exhibited significant responses to various bio-organics and mineral nitrogen levels with respect to plant growth, wheat yield and yield attributes. The application of combination from microbial additives and compost tea with $75 \mathrm{k}$ N/fed revealed optimum treatment under sandy soils in terms of vegetative growth, nutrients content.

\section{REFERENCES}

Ahmad, F., F. M. Husain and I. Ahmad (2011). Rhizosphere and Root Colonization by Bacterial Inoculants and Their Monitoring Methods: A Critical Area in PGPR Research. In: "Microbes and Microbial Technology: Agricultural and Environmental 
Applications", Ahmad, I., F. Ahmad and J. Pichtel, pp. 363-391, Springer, New York, USA.

AOAC (1998). "Official Methods of Analysis of AOAC international". $16^{\text {th }}$ Ed., AOAC International, Gaithersburg, Maryland, USA.

Arya, B., B. R. Komala, N. T. Sumalatha, G. M. Surendra and P. R. Gurumurthy (2018). PGPR induced systemic tolerance in plant. Int. .J. Curr. Microbiol. App. Sci., 7: 453-462.

Atlas, R. M. (2010). "Handbook of Microbiological Media". $4^{\text {th }}$ Ed., CRC Press-Taylor and Francis Group, USA.

Bakker, P. A., R. L. Berendsen, R. F. Doornbos, P. C. Wintermans and C. M. Pieterse (2013). The rhizosphere revisited: root microbiomics. Front Plant Sci., 4: 1-7.

Casida, L. E. J. (1977). Microbial metabolic activity in soil as measured by dehydrogenase determinations. Appl. Environ. Microbiol., 34: 630-6.

Chapman, H. D. and P. F. Pratt (1961). "Methodes of Analysis for Soils, Plants and Water". Riverside, USA, Agric. Publ. Univ. of California.

Chen, Y. P., S. Liu and J. W. Kloepper (1996). The use of yield increasing bacteria as plant growth promoting rhizobacteria in Chinase agriculture. In: "Manegment of soil born diseases", V.K., G. and U. R., pp. 164184, Ludhiana: Kalyani Publishers, New Delhi, India.

Chowdhury, M. A. M. and P. E. Weatherley (1990). A rapid method of estimating the surface area of root system. Tropical Agric. Res., 2: 92100.

Dakora, F. D. and D. A. Phillips (2002). Root exudates as mediators of mineral acquisition in low-nutrient environments. Plant and Soil, 245: 3547.
Desoky, A. H. and H. A. M. El-Sayed (2016). Effect of inoculation with diazotrophs on wheat productivity under different $\mathrm{N}$-fertilizer levels in sandy soils. J. Agric. Chem. Biotechn., Mansoura Univ., 7: 201 - 211.

Dotaniya, M. L. and V. D. Meena (2014). Rhizosphere effect on nutrient availability in soil and its uptake by plants: A review. Proceedings of the National Academy of Sciences, India Section B: Biological Sciences, 85: 112.

El-Egami, H. M. A., Y. A. El-Tahlawy and S. Y. S. El-Sayed (2017). Enhancement the productivity of wheat by improving the efficiency of nonsymbiotic nitrogen fixing bacteria in the presence of some biofertilizers. $\mathrm{N}$. Egypt. J. Microbiol., 46: 51 - 66.

El-Gizawy, E. S. A., A. A. I. Atwa, N. I. Talha and R. A. I. Mostafa (2013). Effect of compost and compost tea application on faba bean crop and some soil biological and chemical properties. J. Soil Sci. Agric. Eng., Mansoura Univ., 4: 863 - 874.

Fouda, S. E. and A. S. Ali (2016). The effects of the conjunctive use of compost tea and inorganic fertilizers on radish (Raphanus sativus) nutrient uptake and soil microorganisms. Egypt. J. Soil Sci., 56: 261-280.

Grimont, F. and P. A. D. Grimont (2006). The Genus Serratia. In: "Prokaryotes", Dworkin, M., S. Falkow, E. Rosenberg, K. H. Schleifer and E. Stackebrandt, pp. 219-244, Springer-Verlag New York, USA.

Guo, H. C., W. B. Wang, X. H. Luo and X. P. Wu (2015). Characteristics of rhizosphere and bulk soil microbial communities in rubber plantations in hainan island, China. Journal of Tropical Forest Science, 27: 202-212. 
Khalil, N. H. and R. J. Agah (2017). Effect of chemical, organic and bio fertilization on growth and yield of strawberry plant. Int. J. Adv. Chem. Eng. Biol. Sci. (IJACEBS), 4: 167-171.

Kim, M. J., C. K. Shim, Y. K. Kim, S. J. Hong, J. H. Park, E. J. Han, J. H. Kim and S. C. Kim (2015). Effect of aerated compost tea on the growth promotion of lettuce, soybean, and sweet corn in organic cultivation. Plant Pathol. J., 31: 259-68.

Kloepper, J. W. and M. N. Schroth (1978). Plant growth-promoting rhizobacteria on radishes. In Station de pathologie vegetale et phyto-bacteriologie. In: "Procceedings of the fourth International Conference on Plant Pathogenic Bacteria", pp. 879-882, Gilbert-Clarey, Tours, France.

Kumar, A., V. K. Singh, V. Tripathi, P. P. Singh and A. K. Singh (2018). Plant Growth-Promoting Rhizobacteria (PGPR): Perspective in Agriculture Under Biotic and Abiotic Stress. In: "New and Future Developments in Microbial Biotechnology and Bioengineering: Crop Improvement through Microbial Biotechnology", $1^{\text {st }}$ Ed., Prasad, R., S. S. Gill and N. Tuteja, pp. 333-342, Elsevier Science, USA.

Kumar, N., H. K. Singh and P. K. Mishra (2015). Impact of organic manures and biofertilizers on growth and quality parameters of strawberry cv. Chandler. Indian J. Science and Technology, 8: 1-6.

Kumar, S., S. Chaudhuri and S. K. Maiti (2013). Soil dehydrogenase enzyme activity in natural and mine soil - A review. Middle-East J. Sci. Res., 13: 898-906.

Ladha, J. K., M. Garcia, S. Miyan, A. T. Padre and I. Watanabe (1989). Survival of Azorhizobium caulinodans in the
Soil and Rhizosphere of Wetland Rice under Sesbania rostrata-Rice Rotation. Appl. Environ. Microbiol., 55: 454-60.

Luz, W. C. d. (2001). Evaluation of plant growth-promoting and bioprotecting rhizobacteria on wheat crop. Fitopatologia Brasileira, 26: 597-600.

Martin, C. C. G. S. (2014). Potential of compost tea for suppressing plant diseases. CAB Reviews: perspectives in agriculture, veterinary science, nutrition and natural resources, 9: 238.

Momin, R. K. and R. M. Dhere (2013). Comparison of rhizospheric and nonrhizospheric soils of some medicinal plants. Adv. Biores., 4: 132-133.

Morgan, J. A., G. D. Bending and P. J. White (2005). Biological costs and benefits to plant-microbe interactions in the rhizosphere. J. Exp. Bot., 56: 1729-39.

Page, A. L., R. H. Miller and D. R. Keeney (1982). "Methods of Soil Analysis". IIChemical and Microbiological Properties, American Soc. of Agronomy, Madison, Wisconsin, USA.

Pant, A. P., T. J. K. Radovich, N. V. Hue, S. T. Talcott and K. A. Krenek (2009). Vermicompost extracts influence growth, mineral nutrients, phytonutrients and antioxidant activity in pak choi (Brassica rapacv. Bonsai, Chinensis group) grown under vermicompost and chemical fertiliser. J. Sci. Food Agric., 89: 2383-2392.

Rana, A., B. Saharan, L. Nain, R. Prasanna and Y. S. Shivay (2012). Enhancing micronutrient uptake and yield of wheat through bacterial PGPR consortia. Soil Science and Plant Nutrition, 58: 573-582.

Reimann, S. and R. A. Sikora (2003). Managing the mycorrhizosphere: An approach to sustainable agriculture 
after the phaseout of methyl bromide. Commun. Agric. Appl. Biol. Sci., 68: 129-34.

Reinhold-Hurek, B., W. Bunger, C. S. Burbano, M. Sabale and T. Hurek (2015). Roots shaping their microbiome: global hotspots for microbial activity. Ann. Rev. Phytopathol., 53: 403-24.

Richardson, A. E., J. M. Barea, A. M. McNeill and C. Prigent-Combaret (2009). Acquisition of phosphorus and nitrogen in the rhizosphere and plant growth promotion by microorganisms. Plant and Soil, 321: 305-339.

Scheuerell, S. J. and W. Mahaffee (2002). Compost tea: principles and prospects for plant disease control. Compost Sci. Util., 10: 313-338.

Snedecor, G. W. and W. G. Cochran (1980). "Statistical Methods" $7^{\text {th }}$ Ed., lowa State Univ. Press, Amr., USA.

Zewail, R. M. Y. and H. S. A. Ahmed (2015). Effect of some biofertilizers (PGPR, biosoal and compost tea) on growth ,yield, fiber quality and yarn properties of Egyptian cotton. (promising hybrid 10229xg86). Annals of Agric. Sci., Moshtohor, 53: 199-210.

Zhu, S., J. M. Vivanco and D. K. Manter (2016). Nitrogen fertilizer rate affects root exudation, the rhizosphere microbiome and nitrogen-useefficiency of maize. Applied Soil Ecology, 107: 324-333. 
تاثير الإضافات الميكروبية و شاي الكمبوست على نمو و إنتاجية نباتات القمح المسمد بالنيتروجين المعدني في الأراضي الرملية

\section{ياسر عربي الطحلاوي}

قسم بحوث الميكروبيولوجيا الزراعية - معهد بحوث الأراضى والمياه والبيئة - مركز البحوث الزراعية ـالجيزة - مصر.

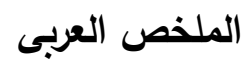

أدت الانتقادات الواسعة للاستفدام المفرط للكيماويات الى الاتجاه الى الزراعة النظيفة المستدامة. تم اجراء تجربة

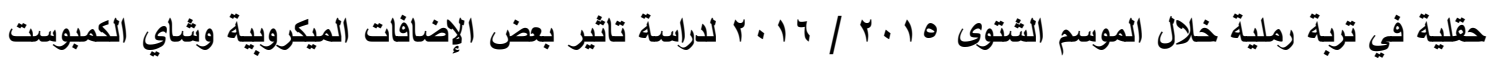
والخليط منهما في وجود مستويات مختلفة من التسميد النيتروجيني المعني على حالة النمو وإنتاجية القدح. وكانت

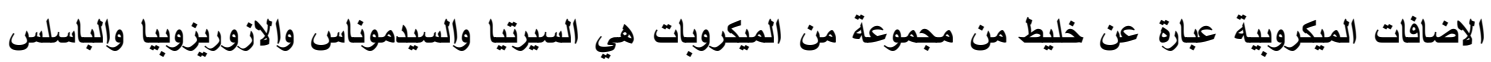

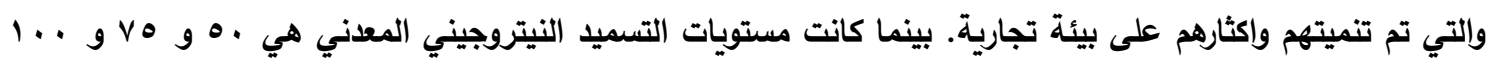

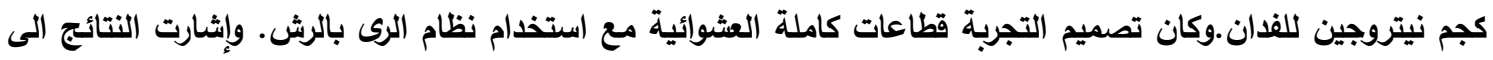

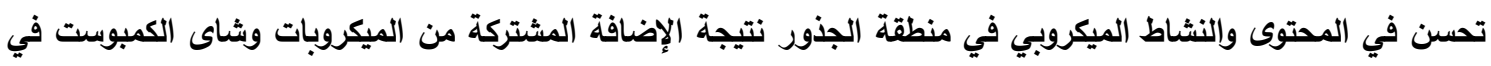

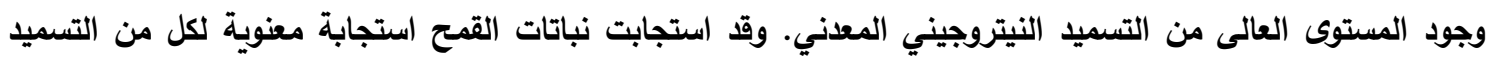

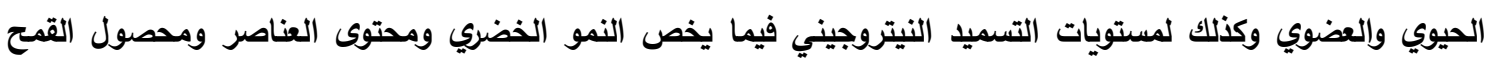

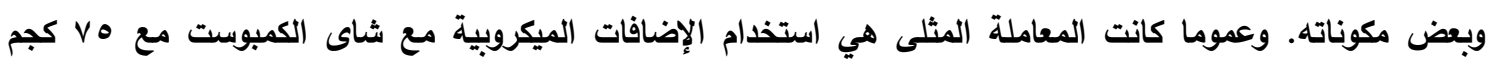

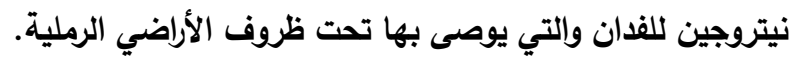

معهد بحوث الأراضى والمياه والبيئة - مركز البحوث الزراعية - الجيزة كلية الزراعة - جامعة المنوفية

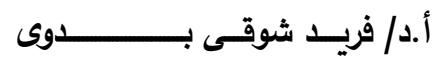

أ.د/ الحسينى عبدالنفار أبو حسين 
